\title{
ABIOTIC STRESS IMPACT ON AEROSOL MASS SPECTRA OVER A FOREST SITE IN LITHUANIA
}

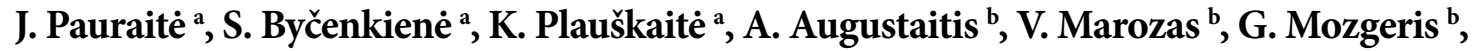 \\ A. Pivoras ${ }^{b}$, G. Pivoras ${ }^{b}$, and V. Ulevičius ${ }^{a}$ \\ ${ }^{a}$ Center for Physical Sciences and Technology, Sauletekio 3, 10257 Vilnius, Lithuania \\ ${ }^{\mathrm{b}}$ Vytautas Magnus University, Studentu 13, 53362 Kaunas, Lithuania \\ Email: julija.pauraite@ftmc.lt
}

Received 26 May 2019; revised 10 September 2019; accepted 30 September 2019

\begin{abstract}
Volatile organic compounds (VOCs) emitted by trees in response to abiotic stress evoke high levels of secondary organic aerosol (SOA) compounds. Few techniques exist to provide chemically-resolved submicron $\left(\mathrm{PM}_{1}\right)$ particle mass concentrations and source apportionment of stress-induced emissions from trees and SOA formation. The chemical composition of atmospheric aerosol particles was characterized using an aerosol chemical speciation monitor (ACSM) at a mixed-mature forest site - the Aukštaitija Integrated Monitoring Station in the eastern part of Lithuania. The organic fraction of $\mathrm{PM}_{1}$ consisted of SOA $(76 \%)$ and of anthropogenic combustion related primary organic aerosol (POA) (24\%). The analysis of tree trunk circumference revealed three shrinkage and three normal increase episodes. During the episodes of tree trunk circumference shrinkage, several $m / z$ signal $(\mathrm{m} / z 42,43,45,48$, 50 ) intensities were found to be magnified together with the daily SOA concentration. The stress response analysis confirm that tree trunk circumference shrinkage may be observed through the enhancement of selected $\mathrm{m} / \mathrm{z}$ signals and result in increased SOA levels.
\end{abstract}

Keywords: aerosol, SOA, ACSM, tree trunk circumference

PACS: 92.60.Mt, 33.15.Ta

\section{Introduction}

Secondary organic aerosol (SOA) formation from the oxidation of biogenic volatile organic compounds (BVOCs) affects the chemical and physical properties of atmosphere aerosol [1, 2. . Thus, taking into account the importance of SOA formation which significantly contributes to particulate matter in the atmosphere, many laboratory studies on determination of the mass and chemical characteristics of the oxidation of different gas phase precursors are of particular interest [3]. It is known that environmental stress conditions, such as periods of abnormally high temperatures, drought and cold, are the ma- jor abiotic stresses that adversely affect tree growth physiology and BVOCs emissions [4-6. Forest defoliation investigations held by a large European forest survey in 2010 found that abiotic factors were linked to $9 \%$ of damaged trees [7].

The sensitivity of Norway spruce annual growth to variations in climate change conditions has also been documented in Lithuania [8, 90. The intensity of tree damage depends on their ability to respond and adapt to environmental changes, which ensures their sustainable development. Under abiotic stress induced BVOC emissions and their concentration can vary significantly [10, 11]. While studies have been performed to quantify stress induced VOCs 
emissions under high ambient temperatures [12, 13, a quantitative understanding of the temperature-response effects on SOA concentration has not yet been attained. In the last decades extensive investigation has been dedicated to the study of stress induced processes associated with the analysis of the mass spectra and the source apportionment of organic aerosol (OA) [14, 15]. Several mass-tocharge ratios $(\mathrm{m} / \mathrm{z})$ were identified as abiotic stress markers in recent studies: $m / z 29\left(\mathrm{C}_{2} \mathrm{H}_{5}^{+}\right), m / z 31$ $\left(\mathrm{CH}_{3} \mathrm{O}^{+}\right), m / z 53\left(\mathrm{C}_{4} \mathrm{H}_{5}^{+}\right), m / z 57\left(\mathrm{C}_{3} \mathrm{H}_{5} \mathrm{O}^{+}\right), m / z 58$ $\left(\mathrm{C}_{2} \mathrm{H}_{2} \mathrm{O}_{2}^{+}, \mathrm{C}_{3} \mathrm{H}_{6} \mathrm{O}^{+}\right), m / z 59\left(\mathrm{C}_{2} \mathrm{H}_{3} \mathrm{O}_{2}^{+}, \mathrm{C}_{3} \mathrm{H}_{7} \mathrm{O}^{+}\right), m / z$ $71\left(\mathrm{C}_{3} \mathrm{H}_{3} \mathrm{O}_{2}^{+}, \mathrm{C}_{4} \mathrm{H}_{7} \mathrm{O}^{+}\right), m / z 82\left(\mathrm{C}_{5} \mathrm{H}_{6} \mathrm{O}^{+}\right)$and $\mathrm{m} / z$ $83\left(\mathrm{C}_{5} \mathrm{H}_{7} \mathrm{O}^{+}\right)$[16, 17]. Determination of changes in SOA concentration related to abiotic stress provides the means of identification of the specific markers to diagnose the state of forests, assessment of their ability to mitigate climate change and evaluation of the impact on the global SOA concentration.

Therefore, the aim of this study was to gain more insight into the $\mathrm{m} / \mathrm{z}$ ratios and to investigate the SOA concentration relationship on the abiotic stress related changes in tree trunk circumference.

\section{Methods}

\subsection{Site description}

The field experiment was performed at the rural site, the Aukštaitija Integrated Monitoring Station (IMS LT01), located in the eastern part of Lithuania $\left(55.46^{\circ} \mathrm{N}, 26.00^{\circ} \mathrm{E}, 160 \mathrm{~m}\right.$ above the sea level) (Fig. 1) in Aukštaitija National Park, distant about $30 \mathrm{~km}$ east of the nearest city, Utena. Vegetation in Aukštaitija is characterized by coniferous (Pinus sylvestris L. and Picea abies Karst.) and mixed forests which cover $70 \%$ of the national park area [18.
The climate of the region is determined by high precipitation and relative humidity (RH) as well as by low ambient temperature with mean annual values of $664 \mathrm{~mm}, 81 \%$ and $6.4^{\circ} \mathrm{C}$, respectively [9, 19-21].

\subsection{Sampling}

\subsubsection{Aerosol chemical composition}

The chemical composition of non-refractory submicron particles was measured using an aerosol chemical speciation monitor (ACSM) (Aerodyne Research, Inc., Billerica, MA, USA). In order to get rid of dust and bigger particles in the sampling line, a selfdesigned $\mathrm{PM}_{10}$ inlet-impactor and a Nafion dryer were used (MD-110-48S-4, Perma Pure LLC, Toms River, NJ, USA). The aerodynamics lenses placed in the ACSM allowed the further segregation by size, which resulted in only $\mathrm{PM}_{1}$ particles being investigated. The sampling aerosol flow was $1.6 \mathrm{l} / \mathrm{min}$. During the instrument calibration, the determined calibration parameters were $\mathrm{RIE}_{\mathrm{Org}}=1.4, \mathrm{RIE}_{\mathrm{NH}_{4}}=9.14$, $\mathrm{RIE}_{\mathrm{SO} 4}=4.2, \mathrm{RIE}_{\mathrm{NO}_{3}}=1.1$ and $\mathrm{RIE}_{\mathrm{Ch}}=1.3$. The response factor was equal to $2.26 \cdot 10^{-11}$. The counting efficiency (CE) was evaluated based on the method suggested by Middlebrook et al. (2012) [22] and was equal to 0.5 . The measurements of mass spectra from 21 to $149 \mathrm{~m} / z$ were undertaken with a time resolution of $30 \mathrm{~min}$. The ACSM measurements were performed during April-September 2016.

\subsubsection{Tree trunk circumference and meteorological parameters}

The tree trunk circumference was measured using a logging band dendrometer (DRL26). During the measurement campaign DRL26 was fixed to

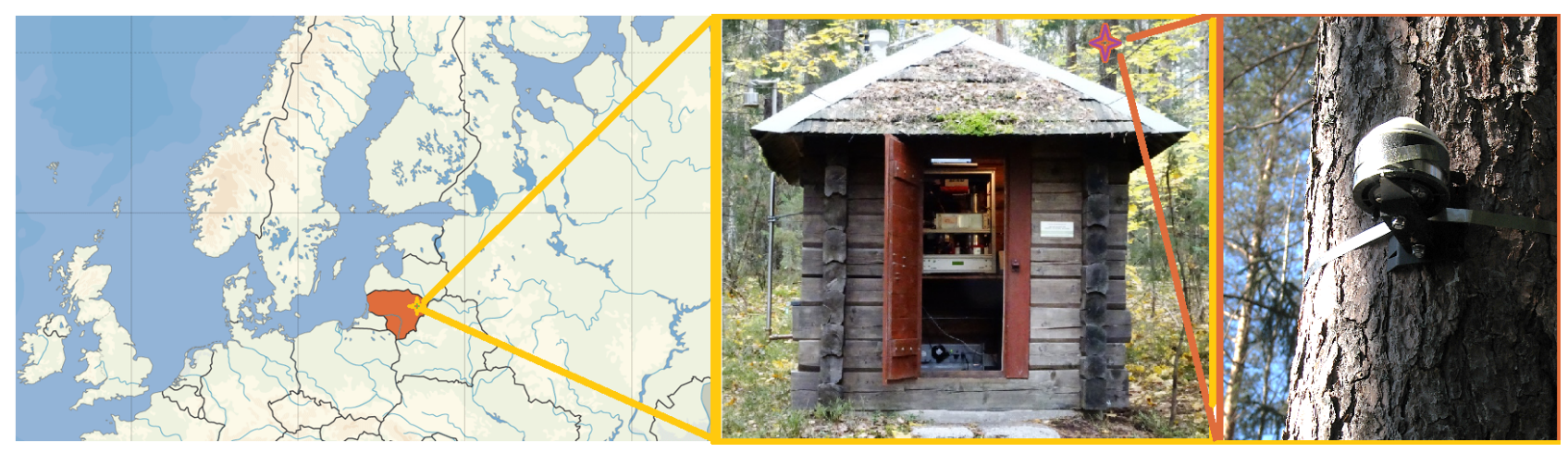

Fig. 1. Location of the Aukštaitija Integrated Monitoring Station (IMS LT01). 
the trunk of both 4 Scots pines (Pinus sylvestris L.) and 3 Norway spruces (Picea abies Karst.). Changes in stem diameter were registered every 1 hour with a resolution of $0.001 \mathrm{~mm}$. The scale of growing rate indicates the number of millimeters increased after the beginning of the measuring campaign. The DRL26 measurements were performed during the period of May-September 2016. All data in this study are reported in local time (GMT +2:00).

Co-located measurements consisted of meteorological condition monitoring such as air temperature at $2 \mathrm{~m}$ height, soil temperature at $0.05 \mathrm{~m}$ depth, average wind speed and solar radiation measurements. All mentioned measurements were performed with a time resolution of 1 hour.

\section{Results and discussion}

\subsection{Campaign overview}

During the measurement campaign in AprilSeptember 2016 the mass concentrations of ammonium, nitrate, sulphate and organic species were evaluated (Fig. 2). Organics contribution to $\mathrm{PM}_{1}$ was dominant and reached $75 \%\left(3.87 \mu \mathrm{g} / \mathrm{m}^{3}\right.$ $\left.\left(\mathrm{SD}=4.31 \mu \mathrm{g} / \mathrm{m}^{3}\right)\right)$ of the total loading. The mass concentration of the sulphate compound was significantly lower $\left(0.68 \mu \mathrm{g} / \mathrm{m}^{3}\left(\mathrm{SD}=0.50 \mu \mathrm{g} / \mathrm{m}^{3}\right)\right)$ and during all the period of measurements the contribution to the total loading was $13 \%$. The average mass concentrations of nitrate and ammonium were $0.35 \mu \mathrm{g} / \mathrm{m}^{3}\left(\mathrm{SD}=0.33 \mu \mathrm{g} / \mathrm{m}^{3}\right)(7 \%$ of total loadings $)$ and $0.27 \mu \mathrm{g} / \mathrm{m}^{3}\left(\mathrm{SD}=0.26 \mu \mathrm{g} / \mathrm{m}^{3}\right)(5 \%$ of total loadings), respectively. The positive matrix factorisation (PMF) analysis of the organic mass spectral dataset distinguished OA into four components, including fresh emission-related oxygenated semi-volatile OA (SV-OOA), aged OA-related low-volatile OA (LV-OOA), biomass burning OA (BBOA) and cooking OA (COA). A detailed description of the PMF analysis has been given previously in Pauraite et al. (2019) [23]. In the current study, the OA factors were divided into SOA and primary $\mathrm{OA}$ (POA). POA is characterized by combustion products and summarises the anthropogenic aerosol contribution to the OA concentration. Thus, due to their anthropogenic origin BBOA and COA were combined and analysed as POA. Meantime, SV-OOA and LV-OOA were grouped into SOA and compared to anthropogenic POA due to their secondary formation. As can be seen in Fig. 2, POA showed minor contribution to OA (24\%). Two events of high COA and BBOA concentrations (up to 40.4 and $21.8 \mu \mathrm{g} / \mathrm{m}^{3}$, respectively) were identified during lunch and dinner hours (11 a.m. -2 p.m. and 6 p.m. -8 p.m.) (15 July and 13 August). The wind rose analysis showed that barbeque and grill cooking activities in neighbourhood villages located next to Utenas Lake (165 m from the measurement site) caused both events. For the following analysis, days with barbeque activities were excluded as analysis was presented in Pauraite et al. (2019) [23]. Thus, such chemical

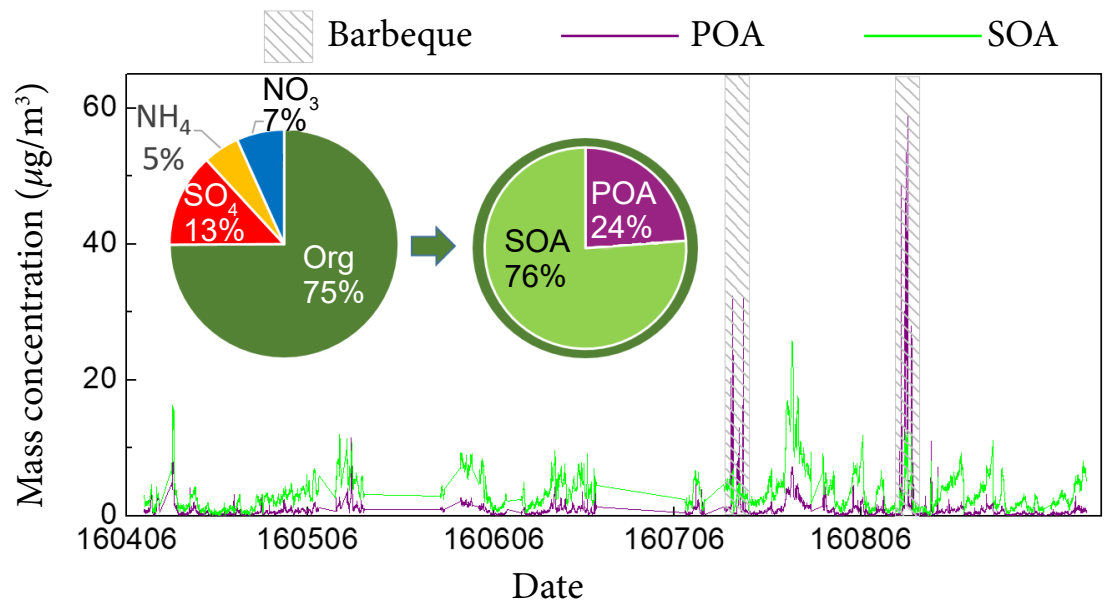

Fig. 2. Contribution of organics (dark green online), sulphate (red), nitrate (blue) and ammonium (yellow) to $\mathrm{PM}_{1}$, contribution of SOA (light green) and POA (purple) to organics and time trends of SOA and POA at IMS LT01 during the measurement campaign. 
composition of $\mathrm{PM}_{1}$ and dominance of SOA versus POA demonstrate a low influence of anthropogenic sources at the IMS LT01 station in Aukštaitija.

\subsection{Changes in tree trunk circumference and its relation to SOA concentration}

In order to understand the relation between the SOA concentration and tree trunk circumference, the tree trunk circumference analysis of Scots pine (Pinus sylvestris L.) and Norway spruce (Picea abies Karst.) was performed. While this study was focused only on the variation of tree trunk circumference, the initial tree trunk circumference of each tree was normalized to the finest tree trunk circumference of each type (Fig. 3). During the measurement campaign the variation of tree trunk circumferences of the selected trees followed a similar pattern: periods of tree trunk circumference increase and shrinkage occurred simultaneously (Fig. 3(a, b)). Moreover, for all selected trees a diurnal variation of the trunk circumference was observed. Herrmann et al. (2016) [24] attribute diurnal variations mainly to transpiration-driven changes in stem water storage.

To investigate the variation of the tree trunk circumference, dendrometer data for each type of trees were averaged and fitted based on the method suggested by Herrmann et al. (2016) [24]. After the fitting, the residuals of the average tree trunk circumference variation were depicted together with the fitted curve normalized to 0 (Fig. 3(c,d)). As can be seen, the variation in the trunk circumference of Scots pines (Pinus sylvestris L.) was quite significant, while the variations in the trunk circumference of Norway spruces (Picea abies Karst.) were relatively smoother. This could be explained by a different
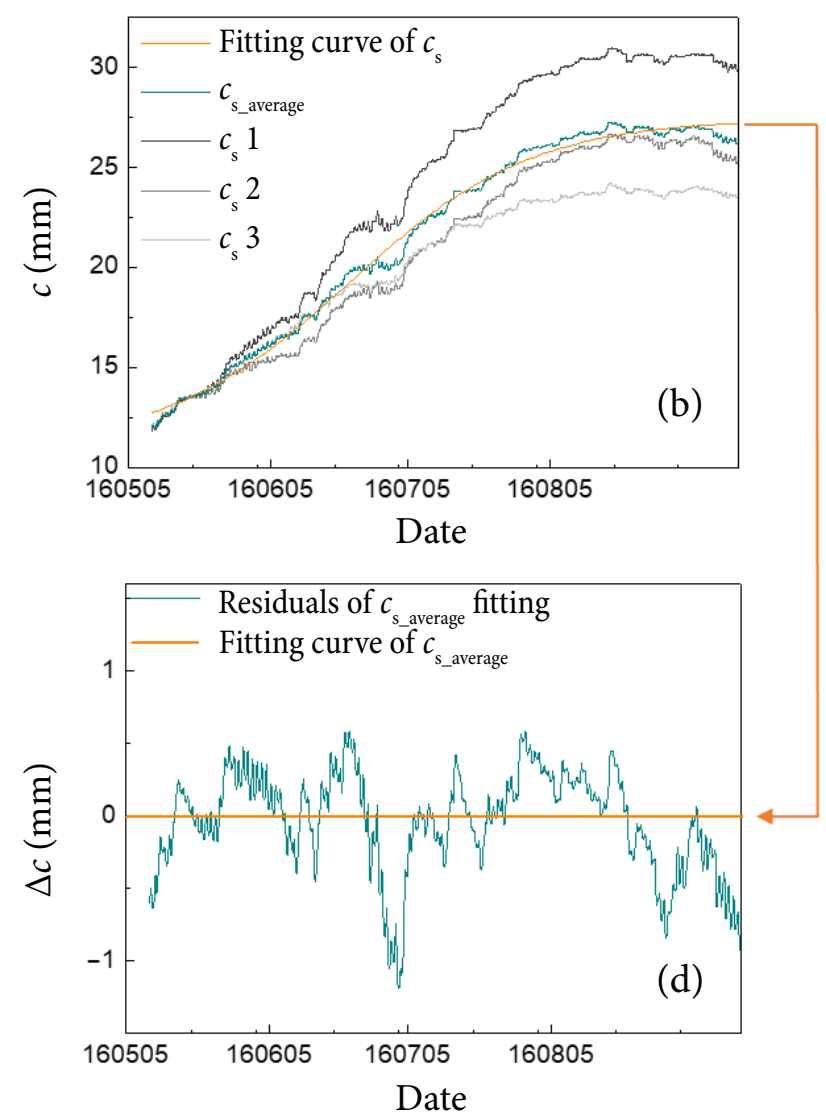

Fig. 3. Variations of the tree trunk circumference $c$ and the fitting curve of its average for Scots pines (Pinus sylvestris L.) (a) and Norway spruces (Picea abies Karst.) (b). Residuals of the tree circumference variation fitting $\Delta c$ and the fitting curve normalized to 0 of Scots pines (Pinus sylvestris L.) (c) and Norway spruces (Picea abies Karst.) (d). Here $c_{\mathrm{p}}$ is the trunk circumference and $c_{\text {paverage }}$ is the averaged trunk circumference of Scots pine (Pinus sylvestris L.); $c_{\mathrm{s}}$ is the trunk circumference and $c_{\text {s_average }}$ is the averaged trunk circumference of Norway spruce (Picea abies Karst.). 
range of the maximum and minimum adaptation to temperature for each species [25]. For this reason, the variations of Scots pines (Pinus sylvestris L.) trunk circumference were used in our study.

On the days with dominant SOA components three events of both increase and shrinkage of the tree trunk circumference were investigated. The duration of each event was from 60 to $90 \mathrm{~h}$. During the events of tree trunk circumference shrinkage, the average air temperature was from 2.7 to $6.5^{\circ} \mathrm{C}$ higher than that for the events with its increase (Table 1). Also, during all three events the average air temperature was higher than the temperature of soil at a depth of $0.1 \mathrm{~m}$. Additional studies have revealed that temperature is the most important limiting factor for tree trunk circumference growth at the upper tree-line [26]. Furthermore, the previous study [27] reported that a significant negative correlation was observed between the daily increase of the tree trunk circumference and the daily mean temperature. The connection between heat stress and tree limbs and trunks is based on desiccation throughout the canopy. Our study of shrinkage events shows a great agreement with the later observation. Mean- while, during the increase events of tree trunk circumference the increase in soil temperature was from 0.8 to $1.7^{\circ} \mathrm{C}$ higher than the average air temperature. This could be explained by normal mechanisms of tree trunk circumference growth during events of suitable circumstances.

Other meteorological parameters such as $\mathrm{RH}$, average wind speed and solar radiation showed a weak correlation with the variation of tree trunk circumference. Even though the influence of individual abiotic stressors was negligible, the sum of several abiotic stressors (solar radiation, RH and temperature) may cause a significant shrinkage in tree trunk circumference. Dong et al. (2012) [28] estimated that when the variability of solar radiation and night-time temperatures were considered together, the correlation with the variation of tree trunk circumference in tropical forests was observed. In our study, during the first and the third events significant shrinkages of tree trunk circumference were observed (2 August 2016 and 9 September 2016) (Fig. 4(a,c)). Moreover, RH and solar radiation changes appeared during both significant shrinkages of tree trunk circumference (Table 1).
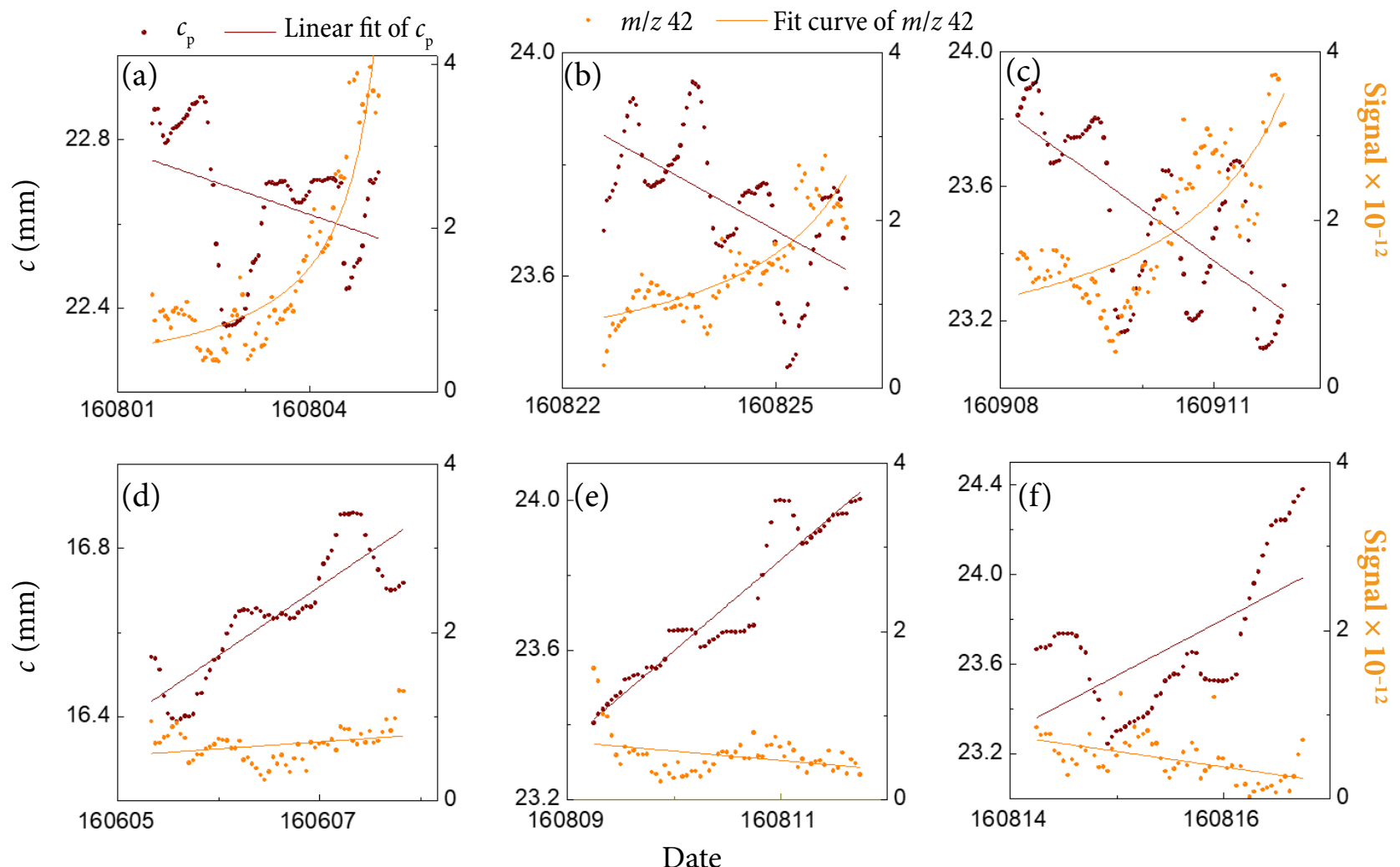

Fig. 4. Variation of the tree trunk circumference $c$ and the signal of $m / z 42$ during (a-c) shrinkage and (d-f) increase events (here $c_{\mathrm{p}}$ is the circumference of Scots pine (Pinus sylvestris L.) trunk). 
Table 1. Summary of the meteorological conditions of all tree trunk circumference increase and shrinkage events.

\begin{tabular}{|c|c|c|c|c|c|c|c|c|}
\hline \multirow{2}{*}{\multicolumn{2}{|c|}{ Event }} & \multirow{2}{*}{$\begin{array}{l}\text { Beginning } \\
\text { date }\end{array}$} & \multirow[t]{2}{*}{ End date } & Soil temp. & Air temp. & \multirow[t]{2}{*}{$\mathrm{RH}$} & \multirow{2}{*}{$\begin{array}{c}\text { Avg.wind } \\
\text { speed }\end{array}$} & \multirow{2}{*}{$\begin{array}{l}\mathrm{UV} \mathrm{A} \\
\mathrm{W} / \mathrm{m}^{2}\end{array}$} \\
\hline & & & & ${ }^{\circ} \mathrm{C}$ & ${ }^{\circ} \mathrm{C}$ & & & \\
\hline \multirow{3}{*}{ 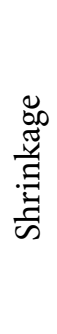 } & S1 & 1 August 2016 & $\begin{array}{l}5 \text { August } \\
2016\end{array}$ & $16.3( \pm 0.6)$ & $16.9( \pm 3.1)$ & $84.6( \pm 13.4)$ & $1.3( \pm 0.7)$ & $4.3( \pm 5.5)$ \\
\hline & S2 & $\begin{array}{l}23 \text { August } \\
2016\end{array}$ & $\begin{array}{l}26 \text { August } \\
2016\end{array}$ & $15.7( \pm 0.6)$ & $16.1( \pm 3.6)$ & $84.6( \pm 13.7)$ & $0.9( \pm 0.4)$ & $4.6( \pm 6.1)$ \\
\hline & S3 & $\begin{array}{c}8 \text { September } \\
2016\end{array}$ & $\begin{array}{l}12 \text { September } \\
2016\end{array}$ & $15.0( \pm 0.7)$ & $16.7( \pm 4.7)$ & $81.4( \pm 15.1)$ & $0.7( \pm 0.5)$ & $3.6( \pm 4.8)$ \\
\hline \multirow{3}{*}{ 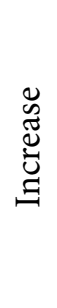 } & I1 & 5 June 2016 & 7 June 2016 & $11.8( \pm 1.0)$ & $10.4( \pm 4.2)$ & $68.5( \pm 15.2)$ & $1.2( \pm 0.5)$ & $5.7( \pm 6.0)$ \\
\hline & $\mathrm{I} 2$ & 9 August 2016 & $\begin{array}{l}12 \text { August } \\
2016\end{array}$ & $15.3( \pm 0.9)$ & $13.0( \pm 2.8)$ & $92.3( \pm 9.1)$ & $0.9( \pm 0.5)$ & $2.3( \pm 4.0)$ \\
\hline & I3 & $\begin{array}{l}15 \text { August } \\
2016\end{array}$ & $\begin{array}{l}17 \text { August } \\
2016\end{array}$ & $14.4( \pm 0.5)$ & $13.4( \pm 1.8)$ & $87.5( \pm 11.2)$ & $1.6( \pm 0.5)$ & $3.5( \pm 4.9)$ \\
\hline
\end{tabular}

On 2 August 2016, between 7 and $15 \mathrm{~h} \mathrm{RH}$ decreased by $44.1 \%$ (from 95.1 to $51.0 \%$ ) and solar radiation increased by $646.7 \mathrm{~W} / \mathrm{m}^{2}$ and reached the third highest value in August $\left(745.3 \mathrm{~W} / \mathrm{m}^{2}\right)$. The air temperature during these hours increased by $7.5^{\circ} \mathrm{C}$ and reached the daily peak of $22.2^{\circ} \mathrm{C}$. As a result, the tree trunk circumference shrank by $0.5 \mathrm{~mm}$ (from 22.9 to $22.4 \mathrm{~mm}$ ). Similar meteorological conditions were observed on 9 September 2016 between 7 and $15 \mathrm{~h}$ : the RH dropped from 95 to $42 \%$, the solar radiation reached the second highest daily peak in September $\left(637.4 \mathrm{~W} / \mathrm{m}^{2}\right)$ and the air temperature rose from 6.2 to $21.7^{\circ} \mathrm{C}$. Consequently, a sum of all these alternations was led by a significant change in shrinkage of the tree trunk circumference from 23.8 to $23.2 \mathrm{~mm}$. Meantime, during the second shrinkage of the tree trunk circumference event (23-27 August 2016) (Fig. 4(b)) no significant changes in $\mathrm{RH}$ and solar radiation appeared: the average $\mathrm{RH}$ was $81 \%(\mathrm{SD}=15.9 \%)$ and the maximum value of solar radiation reached $706.9 \mathrm{~W} / \mathrm{m}^{2}$. Only the air temperature showed unusual values and varied from 8 to $27^{\circ} \mathrm{C}$ indicating one of the hottest days in August 2016. During all three events the average wind speed varied from $0.7 \mathrm{~m} / \mathrm{s}$ $(\mathrm{SD}=0.5 \mathrm{~m} / \mathrm{s})$ to $1.3 \mathrm{~m} / \mathrm{s}(\mathrm{SD}=0.7 \mathrm{~m} / \mathrm{s})$ which can be determined as mild wind. Thus, during the first and the third events, significant changes in tree trunk circumference appeared due to changes in various meteorological parameters $(\mathrm{RH}$, solar radiation and temperature), while during the second event only air temperature showed unusual high values and no sudden changes in other meteorological parameters occurred.

During the tree trunk circumference increase events other meteorological parameters, such as $\mathrm{RH}$, average wind speed and solar radiation, showed no significant changes or unusual values (Fig. $4(\mathrm{~d}-\mathrm{f})$ ). During the days of tree trunk circumference increase events the average of $\mathrm{RH}$ varied from $71.3 \%$ ( $\mathrm{SD}=14.2 \%$ ) (the first event, 5-7 June 2016 ) to $90.7 \%$ ( $\mathrm{SD}=7.9 \%$ ) (the second event, 9-11 August 2016). Solar radiation daily peaks varied between $559.7 \mathrm{~W} / \mathrm{m}^{2}$ (the second event) and $694.1 \mathrm{~W} / \mathrm{m}^{2}$ (the first event) and were lowest compared with 2 days before and after the events. The maximum values of air temperature were from $17.2^{\circ} \mathrm{C}$ of the first event to $21.3^{\circ} \mathrm{C}$ of the second event. The average wind speed varied from $1.0 \mathrm{~m} / \mathrm{s}$ $(\mathrm{SD}=0.5 \mathrm{~m} / \mathrm{s})$ during the second event to $1.6 \mathrm{~m} / \mathrm{s}$ $(\mathrm{SD}=0.5 \mathrm{~m} / \mathrm{s})$ during the third event. Thus, during the tree trunk circumference increase events the investigated meteorological parameters $(\mathrm{RH}$, air temperature, solar radiation and wind speed) 
showed no significant changes and could be described as suitable for normal mechanisms of tree trunk circumference growth.

In addition to the variation of tree trunk circumference dependence on the meteorological parameters, an interaction between these parameters and aerosol mass spectra was determined. After the investigation of all measured $m / z$ signals (from $\mathrm{m} / z 12$ to 149 ) during the tree trunk circumference shrinkage events, several $\mathrm{m} / z$ signals showed a significant response. The intensity of $m / z 42\left(\mathrm{C}_{2} \mathrm{H}_{2} \mathrm{O}^{+}\right)$, $43\left(\mathrm{C}_{2} \mathrm{H}_{3} \mathrm{O}^{+}\right), 45\left(\mathrm{C}_{2} \mathrm{H}_{5} \mathrm{O}^{+}\right), 48\left(\mathrm{C}_{4}^{+}\right)$and $50\left(\mathrm{C}_{4} \mathrm{H}_{2}^{+}\right)$ signals increased from 5.7 to 8.8 times during the all three events (calculated for daytime and nighttime averaged values). While analysing the selected $\mathrm{m} / \mathrm{z}$ signals during the tree trunk circumference shrinkage events, all showed the same tendency, therefore only $m / z 42$ was depicted (Fig. 4). Meanwhile, the intensities of other possible abiotic stress markers $(m / z 29,31,53,57,58,59,71,82$ and $m / z 83$ [16, 17) increased not significantly (from 2.4 to 4.0 times) following changes of SOA.

The increase in the intensity of the selected $\mathrm{m} / \mathrm{z}$ signals appeared a few hours later than the shrinkage had started. This could be explained by a complex tree response in order to resist the heat and potentially other abiotic stress factors. Meanwhile, during the events of the tree trunk circumference increase no significant change in the selected $\mathrm{m} / \mathrm{z}$ signals intensity was observed. Moreover, no clear pattern of changes in the selected $\mathrm{m} / z$ signals intensity with time appeared, which indicates normal functions of a tree with no stress induced BVOC emissions.

SOA concentration during all events was analysed. During the shrinkage events, the SOA daily concentration significantly increased. The following day after the first shrinkage event on 2 August, the SOA concentration increased by 1.3 times (from 1.31 to $1.74 \mu \mathrm{g} / \mathrm{m}^{3}$ ) and showed a tendency to continue increasing until 5 August when reached $6.16 \mu \mathrm{g} / \mathrm{m}^{3}$. During the second shrinkage event on 23-27 August, the SOA concentration was constantly increasing from 2.18 to $7.05 \mu \mathrm{g} / \mathrm{m}^{3}$. The third event, which took place on 9-11 September, resulted in the SOA daily concentration increase from 1.99 to $5.38 \mu \mathrm{g} / \mathrm{m}^{3}$. Thus, during the first, the second and the third event, the SOA concentration increased by 4.7, 3.2 and 2.7 times, respectively. Meanwhile, during all three events of tree trunk circumference increase no significant change in SOA was observed.

To conclude, the tree response to stress factors by shrinkage of the tree trunk circumference may be followed by increase in the intensity of the $m / z \quad 42\left(\mathrm{C}_{2} \mathrm{H}_{2} \mathrm{O}^{+}\right), 43\left(\mathrm{C}_{2} \mathrm{H}_{3} \mathrm{O}^{+}\right), 45\left(\mathrm{C}_{2} \mathrm{H}_{5} \mathrm{O}^{+}\right)$, $48\left(\mathrm{C}_{4}^{+}\right)$and $50\left(\mathrm{C}_{4} \mathrm{H}_{2}^{+}\right)$signals and at least twice increased the SOA concentration. These findings support the hypothesis that the increased intensity of the selected $\mathrm{m} / z$ signals is associated with the biogenic stress response and the abiotic stress is an important factor for SOA formation and concentration levels.

\section{Conclusions}

The results of tree trunk circumference investigation have revealed that both the dominant coniferous species, Scots pines (Pinus sylvestris L.) and Norway spruces (Picea abies Karst.), have a similar growth rate pattern. Nevertheless, the influence of individual abiotic stressors was negligible, however, the sum of several abiotic stressors (solar radiation, $\mathrm{RH}$ and temperature) may cause a significant shrinkage in the tree trunk circumference. During the events of tree trunk circumference shrinkage, a great increase of intensities of the selected $\mathrm{m} / \mathrm{z}$ signals $(m / z 42,43,45,48,50)$ as well as the increase of the daily concentration of SOA was observed (up to 4.7 times). Meanwhile, the increase in the tree trunk circumference has shown no influence on the intensity of $m / z$ signals and the SOA daily concentration. These findings suggest that the response to abiotic stress related factors may result in changes in aerosol mass spectra and an increased level of aerosol concentration.

\section{Acknowledgements}

This work was supported by the National Research Programme 'Sustainability of Agro-, Forest and Water Ecosystems', Project FOREstRESS (No. SIT-3/2015).

\section{References}

[1] F. Brilli, T. Tsonev, T. Mahmood, V. Velikova, F. Loreto, and M. Centritto, Ultradian variation of isoprene emission, photosynthesis, mesophyll conductance, and optimum temperature 
sensitivity for isoprene emission in water-stressed Eucalyptus citriodora saplings, J. Exp. Bot. 64, 519-528 (2013), https://doi.org/10.1093/jxb/ers353

[2] Ü. Niinemets, U. Kuhn, P.C. Harley, M. Staudt, A. Arneth, A. Cescatti, P. Ciccioli, L. Copolovici, C. Geron, A. Guenther, et al., Estimations of isoprenoid emission capacity from enclosure studies: Measurements, data processing, quality and standardized measurement protocols, Biogeosciences 8, 2209-2246 (2011), https://doi. org//10.5194/bg-8-2209-2011

[3] M. Glasius and A.H. Goldstein, Recent discoveries and future challenges in atmospheric organic chemistry, Environ. Sci. Technol. 50, 2754-2764 (2016), https://doi.org/10.1021/acs.est.5b05105

[4] A. Gazol, J.J. Camarero, W.R.L. Anderegg, and S.M. Vizcente-Serrano, Impacts of droughts on the growth resilience of Northern Hemisphere forests, Glob. Ecol. Biogeogr. 26, 166-176 (2017), https://doi.org/10.1111/geb.12526

[5] R. Bergström, M. Hallquist, D. Simpson, J. Wildt, and T.F. Mentel, Biotic stress: A significant contributor to organic aerosol in Europe? Atmos. Chem. Phys. 14, 13643-13660 (2014), https://doi. org/10.5194/acp-14-13643-2014

[6] E. Kleist, T.F. Mentel, S. Andres, A. Bohne, A. Folkers, A. Kiendler-Scharr, Y. Rudich, M. Springer, R. Tillmann, and J. Wildt, Irreversible impacts of heat on the emissions of monoterpenes, sesquiterpenes, phenolic BVOC and green leaf volatiles from several tree species, Biogeosciences 9, 51115123 (2012), https://doi.org/10.5194/bg-9-51112012

[7] R. Fischer, P. Waldner, J. Carnicer, M. Coll, M. Dobbertin, M. Ferretti, K. Hansen, G. Kindermann, P. Lasch-Born, M. Lorenz, et al., The Condition of Forests in Europe, 2012 Executive Report (ICP Forests, Hamburg, 2012).

[8] V. Stakènas, P. Žemaitis, and R. Ozolinčius, Crown condition of Norway spruce in different eco-climatic regions of Lithuania: Implications for future climate, Balt. For. 18, 187-195 (2012).

[9] A. Augustaitis, I. Augustaitienè, M. Baugarten, S. Bičenkienė, R. Girgždienè, G. Kulbokas, E. Linkevičius, V. Marozas, M. Mikalajūnas, G. Mordas, et al., Tree-ring formation as an indicator of forest capacity to adapt to the main threats of environmental changes in Lithuania, Sci. Total Environ. 615, 1247-1261 (2018), https://doi.org/10.1016/j. scitotenv.2017.09.169

[10]J. Peñuelas and M. Staudt, BVOCs and global change, Trends Plant Sci. 15, 133-144 (2010), https://doi.org/10.1016/j.tplants.2009.12.005

[11]F. Loreto and J.P. Schnitzler, Abiotic stresses and induced BVOCs, Trends Plant Sci. 15, 154-166 (2010), https://doi.org/10.1016/j. tplants.2009.12.006

[12]E.L. Singsaas and T.D. Sharkey, The effects of high temperature on isoprene synthesis in oak leaves, Plant. Cell Environ. 23, 751-757 (2000), https:// doi.org/10.1046/j.1365-3040.2000.00582.x

[13]T.D. Sharkey, E.L. Singsaas, P.J. Vanderveer, and C. Geron, Field measurements of isoprene emission from trees in response to temperature and light, Tree Physiol. 16, 649-654 (1996), https:// doi.org/10.1093/treephys/16.7.649

[14]A. Kiendler-Scharr, Q. Zhang, T. Hohaus, E. Kleist, A. Mensah, T.F. Mentel, C. Spindler, R. Uerlings, R. Tillmann, and J. Wildt, Aerosol mass spectrometric features of biogenic SOA: Observations from a plant chamber and in rural atmospheric environments, Environ. Sci. Technol. 43, 8166-8172 (2009), https://doi. org/10.1021/es901420b

[15]C.L. Faiola, M. Wen, and T.M. Vanreken, Chemical characterization of biogenic secondary organic aerosol generated from plant emissions under baseline and stressed conditions: Inter- and intra-species variability for six coniferous species, Atmos. Chem. Phys. 15, 3629-3646 (2015), https://doi.org/10.5194/acp-15-3629-2015

[16]W.W.Hu, P.Campuzano-Jost, B.B. Palm, D.A. Day, A.M. Ortega, P.L. Hayes, J.E. Krechmer, Q. Chen, M. Kuwata, Y.J. Liu, et al., Characterization of a real-time tracer for isoprene epoxydiols-derived secondary organic aerosol (IEPOX-SOA) from aerosol mass spectrometer measurements, Atmos. Chem. Phys. 15, 11807-11833 (2015), https://doi.org/10.5194/acp-15-11807-2015

[17]S.H. Budisulistiorini, K. Baumann, E.S. Edgerton, S.T. Bairai, S. Mueller, S.L. Shaw, E.M. Knipping, A. Gold, and J.D. Surratt, Seasonal 
characterization of submicron aerosol chemical composition and organic aerosol sources in the southeastern United States: Atlanta, Georgia, and Look Rock, Tennessee, Atmos. Chem. Phys. 16, 5171-5189 (2016), https://doi.org/10.5194 acp-16-5171-2016

[18]A. Augustaitis, Impact of meteorological parameters on responses of pine crown condition to acid deposition at Aukštaitija National Park, Balt. For. 17, 205-214 (2011).

[19]A. Augustaitis, D. Šopauskienè, and I. Baužienè, Direct and indirect effects of regional air pollution on tree crown defoliation, Balt. For. 16, 2334 (2010).

[20]A. Augustaitis, I. Augustaitienè, A. Kliučius, G. Pivoras, D. Šopauskiene, and R. Girgždiené, The seasonal variability of air pollution effects on pine conditions under changing climates, Eur. J. For. Res. 129, 431-441 (2010), https://doi. org/10.1007/s10342-009-0319-x

[21] A.M. Middlebrook, R. Bahreini, J.L. Jimenez, and M.R. Canagaratna, Evaluation of compositiondependent collection efficiencies for the aerodyne aerosol mass spectrometer using field data, Aerosol Sci. Technol. 46, 258-271 (2012), https:// doi.org/10.1080/02786826.2011.620041

[22]A. Augustaitis, K. Arbačiauskas, I. Baužienè, I. Eitminavičiūtè, R. Girgždienè, A. Kliučius, R. Mažeikytė, G. Mozgeris, V. Rašomavičius, and D. Šopauskiené, Sąlygiškai natūraliu ekosistemu kompleksiškas monitoringas (Lututè, Vilnius, 2006) [in Lithuanian].

[23]J. Pauraitė, A. Pivoras, K. Plauškaitè, S. Byčenkienè, G. Mordas, A. Augustaitis, V. Marozas, G. Mozgeris, M. Baumgarten, R. Matyssek, et al., Characterization of aerosol mass spectra responses to temperature over a forest site in Lithuania, J. Aerosol Sci. 133, 56-65 (2019), https://doi.org/10.1016/j.jaerosci.2019.03.010

[24] V. Herrmann, S.M. McMahon, M. Detto, J.A. Lutz, S.J. Davies, C.H. Chang-Yang, and K.J. AndersonTeixeira, Tree circumference dynamics in four forests characterized using automated dendrometer bands, PLoS ONE 11, 1-20 (2016), https:// doi.org/10.1371/journal.pone.0169020

[25]N. Kaushal, K. Bhandari, K.H.M. Siddique, and H. Nayyar, Food crops face rising temperatures: An overview of responses, adaptive mechanisms, and approaches to improve heat tolerance, Cogent Food Agric. 2, 1-42 (2016), https://doi.or g/10.1080/23311932.2015.1134380

[26]X. Gou, F. Zhang, Y. Deng, G.J. Ettl, M. Yang, L. Gao, and K. Fang, Patterns and dynamics of tree-line response to climate change in the eastern Qilian Mountains, northwestern China, Dendrochronologia 30, 121-126 (2012), https:// doi.org/10.1016/j.dendro.2011.05.002

[27]Z. Wang, B. Yang, A. Deslauriers, and A. Bräuning, Intra-annual stem radial increment response of Qilian juniper to temperature and precipitation along an altitudinal gradient in northwestern China, Trees 29, 25-34 (2015), https://doi. org/10.1007/s00468-014-1037-7

[28]S.X. Dong, S.J. Davies, P.S. Ashton, S. Bunyavejchewin, M.N.N. Supardi, A.R. Kassim, S. Tan, and P.R. Moorcroft, Variability in solar radiation and temperature explains observed patterns and trends in tree growth rates across four tropical forests, Proc. R. Soc. B 279, 3923-3931 (2012), https://doi.org/10.1098/rspb.2012.1124 


\title{
ABIOTINIO STRESO İTAKA AEROZOLIO DALELIŲ MASĖS SPEKTRUI MIŠKO APLINKOJE LIETUVOJE
}

\author{
J. Pauraite ${ }^{\text {a }}$, S. Byčenkienè ${ }^{a}$, K. Plauškaitè ${ }^{a}$, A. Augustaitis ${ }^{b}$, V. Marozas ${ }^{b}$, G. Mozgeris ${ }^{b}$, A. Pivoras ${ }^{b}$, \\ G. Pivoras ${ }^{b}$, V. Ulevičius ${ }^{a}$ \\ ${ }^{a}$ Fiziniu ir technologijos mokslu centras, Vilnius, Lietuva \\ ${ }^{\mathrm{b}}$ Vytauto Didžiojo universitetas, Kaunas, Lietuva
}

\section{Santrauka}

Abiotinio streso veikiami medžiai išskiria lakius organinius junginius (LOJ), kurie yra antrinių aerozolio daleliu (SOA) prekursoriai. Tyrimo tikslas buvo atlikti submikroninių aerozolio dalelių $\left(\mathrm{PM}_{1}\right)$ masès koncentracijos tyrimus ir šaltinių kilmès atskyrimą medžių abiotinio streso sąlygomis formuojantis SOA. Aerozolio chemine sudètis Aukštaitijos integruotoje monitoringo stotyje (IMS LT01) rytineje Lietuvos dalyje mišraus miško aplinkoje buvo išmatuota aerozolio cheminès sudèties monitoriumi (ACSM). Nustatyta, kad PM 1 organikos frakcija sudaryta iš antrinių (76\%) ir pirminių
\end{abstract}

(24\%) aerozolio dalelių. Medžio kamieno skersmens pokyčių analizè parodè tris medžio kamieno skersmens augimo ir susitraukimo epizodus. Esant abiotinio streso sąlygoms, vyksta medžių kamienų skersmens susitraukimo epizodai, todèl išauga $\mathrm{m} / z 42,43,45,48$ ir 50 signalų intensyvumai nuo 5,7 iki 8,8 kartų, o SOA paros koncentracija padideja nuo 2,7 iki 4,7 kartų. Iprastai augant medžio kamieno skersmeniui $\mathrm{m} / z$ signalų intensyvumai ir SOA koncentracija nekinta. Galima teigti, kad augalu patiriamo abiotinio streso atsakas gali būti identifikuojamas per nustatytų $\mathrm{m} / z$ signalų intensyvumų pokyčius ir lemti padidejusią SOA koncentraciją. 